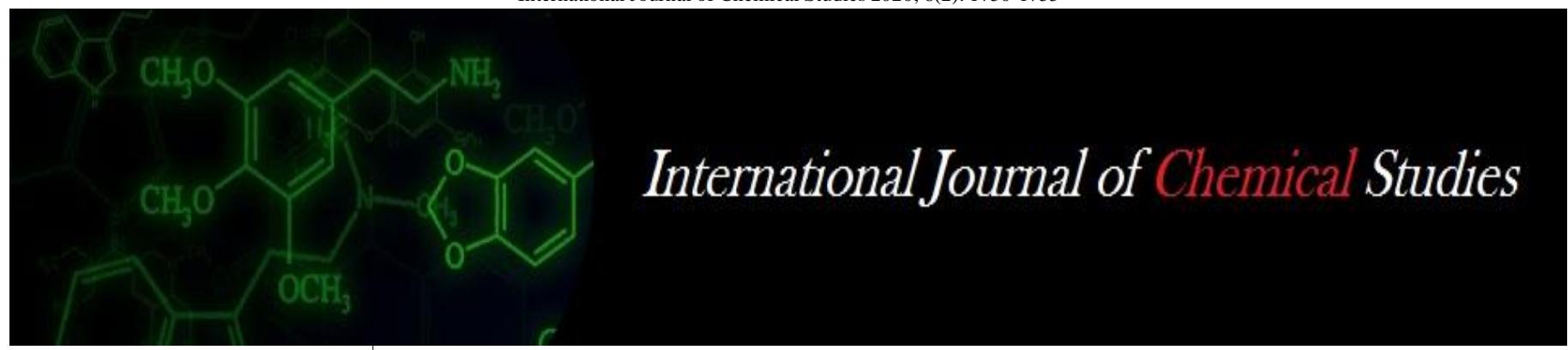

P-ISSN: 2349-8528

E-ISSN: 2321-4902

www.chemijournal.com

IJCS 2020; 8(2): 1750-1755

(C) 2020 IJCS

Received: 18-01-2020

Accepted: 20-02-2020

Alagupalamuthirsolai M

ICAR-Indian Institute of Spices

Research, Calicut, India

Ankegowda SJ

ICAR-Indian Institute of Spices

Research, Regional Station,

Madikeri, India

Mohammad Faisal Peeran

ICAR-Indian Institute of Spices

Research, Regional Station,

Madikeri, India

Sharon Aravind

ICAR-Indian Institute of Spices Research, Calicut, India
Corresponding Author: Alagupalamuthirsolai M ICAR-Indian Institute of Spices Research, Calicut, India

\section{Establishment of a rapid screening method for drought tolerance of small cardamom by using polyethylene glycol-6000}

\section{Alagupalamuthirsolai M, Ankegowda SJ, Mohammad Faisal Peeran and Sharon Aravind}

DOI: https://doi.org/10.22271/chemi.2020.v8.i2aa.9013

\begin{abstract}
Small cardamom is a premier spices crop of India. Drought is the chief abiotic stress causing up to 50$80 \%$ crop loss in small cardamom. Lack of accurate screening techniques is a limiting factor to develop small cardamom cultivars tolerant to drought, which is the most important constraint in small cardamom productivity. In order to optimize the osmotic stress induced by different concentrations of PEG-6000 for moisture stress tolerance screening in small cardamom, a laboratory experiment was conducted in a factorial randomized complete design with four replications. Four different concentrations of PEG-6000 (5, 10, 15 and 20 per cent) along with a control were used in small cardamom cv. Appangala-1. PEG-6000 concentration above $15 \%$ has reduced per cent seedling survival almost by $50 \%$. However, at 15\% PEG-6000, a significant increase in proline, phenolic content and scavenging enzyme activity and decreased chlorophyll fluorescence were recorded. Hence, 15\% PEG-6000 appears to be an ideal concentration for screening of small cardamom genotypes for moisture stress tolerance.
\end{abstract}

Keywords: Small cardamom, drought stress, rapid screening, PEG 6000, phenolics, Antioxidant enzymes

\section{Introduction}

Drought is one of major abiotic stresses constraining crop productivity worldwide; it has negative effect on carbon assimilation through reduction in photosynthesis rate, which results in plant growth reduction and yield (Singh et al., 2014). Severe drought stress also inhibits the photosynthesis of plants by causing changes in the chlorophyll content and damaging the photosynthetic apparatus (Dalton et al., 1998) ${ }^{[8]}$. Generally, drought stress induces the accumulation of reactive oxygen species (ROS) in plants and breaks cellular physiological homeostasis (Xu et al., 2010 and Fernandez-Ocana et al., 2011) ${ }^{[32,11]}$. Higher plants have active oxygen-scavenging systems, such as the antioxidant enzymes superoxide dismutase (SOD), Ascorbate Peroxidase (APX), Catalase (CAT) and Polyphenol oxidase (PPO) protect membranes from the deleterious effects of Reactive oxygen species (ROS) (Foyer and Noctor 2005) ${ }^{[12]}$. Drought stress induces the accumulation of compatible osmolytes like proline in drought tolerant plants and controls osmotic regulation and alleviates stress in cell membranes. It also acts as a protective agent for enzymes function and as a free radical scavenger (Kishor and Sreenivasulu, 2014) ${ }^{[20]}$. Abiotic stress condition results the metabolic processes shifted towards biosynthesis of highly reduced phenolics in the plants for tolerance and prevent the oxidative damage of the cells (Alagupalamuthirsolai et al., 2018) ${ }^{[1]}$. Drought stress inhibits that the light harvesting efficiency, photochemical conversion and photosynthetic electron transport, which must affect the yield and quality of crops (Zhang et al., 2017) ${ }^{[34]}$.

Small cardamom (Elettaria cardamomum (L.) Maton, Zingiberaceae), a shade-loving herbaceous shrub, popularly called "Queen of spices. It is cultivated extensively in the altitude ranging from 500-1500 $\mathrm{m}$ above MSL with an average annual rainfall between 1500 to 5000 $\mathrm{mm}$ and annual lowest and highest temperature varying from $10{ }^{\circ} \mathrm{C}$ to $36{ }^{\circ} \mathrm{C}$. Cardamom is grown in India with a production of 20,650 MT (Spices Board, 2017-18). Cardamom is a high value (second costliest crop in the world after saffron) and high income crop, sensitive to both biotic and abiotic stresses (Murugan et al., 2008) ${ }^{[27]}$. 
Reduced soil water content can decrease the yield of cardamom significantly during summer in the months of April and May (Murugan et al., 2008) ${ }^{[27]}$. The sharp decline in area under cardamom was noticed across the cardamom tracts of Western Ghats in recent decades. The failure of showers during this period results in affects panicle initiation, subsequent growth and crop yield. The unprecedented drought in summer 1983 adversely affected the growth and yield of cardamom in south India and resulted in as high as 50\% mortality in some of the estates. There is a close relationship between cardamom production and rainfall distribution during summer. Summer rain during March, 2008 have benefited the cardamom crop of 2008-2009 up to 20-30\%. Therefore, summer rains have positive influence on cardamom. There exists a strong relationship between the water deficit during summer and cardamom production (Prasada Rao, 2016) ${ }^{[29] .}$

The analysis of plant growth, photosynthetic traits, secondary metabolites and antioxidant capacity in plants exposed to drought stress appears to be a promising approach to identify the deleterious effects of water deficit in small cardamom.

Polyethylene glycol (PEG) has been used as osmoticum to induce water stress on plant tissues (Meneses et al., 2011) ${ }^{[24]}$. The PEG molecules are too large to be absorbed by plant roots, thus increased PEG concentration in the surrounding medium causes outward movement of water from the plant cells (Mohammadkhani et al., 2008) ${ }^{[25]}$. Thus plant cells undergo situations of water stress (Hamayun et al., 2010) ${ }^{[15]}$. Under PEG induced water stress, resistant lines have been reported in tomato (Claussen et al., 2005) ${ }^{[6]}$, and soybean (Sakthivelu et al., 2008) ${ }^{[30]}$.

This study was conducted to assess the effects of PEGinduced drought on seedlings survival and physio-chemical characters of small cardamom; to distinguish the treatment that is most suitable for classifying the small cardamom on the basis of tolerance to early-imposed drought; as well as to distinguish populations which could be used for breeding tolerant varieties.

\section{Materials and methods}

The 45 days old small cardamom seedlings (cv. Appangala-1) were obtained from ICAR-Indian Institute of Spices Research, Regional station, Madikeri. Good quality of plastic containers with size $28 \times 21.5 \times 5 \mathrm{~cm}$ were selected to take nutrient solution. Slightly large sized thermocol sheet of size $35 \times 25.5 \times 4 \mathrm{~cm}$ having holes of $5 \times 5 \mathrm{~mm}$ were placed above the thermocol sheet. The roots of the seedlings were inserted through the holes of the sheet in to the nutrient solution taken in the container. The piece of foam sheet was tied around the color region on the sheet to provide a mechanical support to the seedlings. The sheets were placed in such a way that only the roots become in touch with the nutrient solution. Four trays for each treatment were taken and $1500 \mathrm{ml}$ of Modified Hoagland solution (Epstein, E. (1972) ${ }^{[9]}$ was added to all the treatment trays. The seedling of the small cardamom were subjected to osmotic stress at seedling stage induced by PEG6000 at different concentrations viz., 5, 10, 15, 20 per cent in 4 replications. For control, modified Hoagland solution was applied without PEG-6000 solution.

Random sampling was followed by collecting a minimum of four plants from the trays of each treatment at intervals of 15 days from the day of treatment. The collected plants were thoroughly washed in tap water, blotted to remove water adhered on it and separated into root and leaves. All these samples were used separately for various studies. The observations on seedling survival and physio-chemical constituents were recorded 15 days after treatment incubation.

\section{Total chlorophyll and soluble protein measurement}

All biochemical measurements were carried out on four fresh fully expanded leaves each from the four plants.

Chlorophyll 'a', chlorophyll ' $\mathrm{b}$, and total chlorophyll content were estimated by adopting the method of Yang et al. (2014) ${ }^{[33]}$ and expressed as $\mathrm{mg} \mathrm{g}^{-1}$ of fresh weight. Soluble protein content was estimated with TCA extract of leaves sample following the method of Lowry et al. (1957) and expressed in $\mathrm{mg} \mathrm{g}^{-1}$ fresh weight.

\section{Total phenols and proline measurement}

The total phenolic content of the leaves extract was determined by the Folin-Ciocalteu method (Kaur and Kapoor, 2002) ${ }^{[19]}$. The total phenolic content was calculated from the calibration curve and expressed as $\mathrm{mg} \mathrm{g}^{-1}$ of fresh weight. Proline content of the leaf sample was estimated by the method of Bates et al. (1973) ${ }^{[2]}$ and expressed as $\mu \mathrm{g} \mathrm{g}^{-1}$ of fresh weight.

\section{Analysis antioxidant enzyme activities Assay of superoxide dismutase (SOD)}

The enzyme extract was prepared by homogenizing $1 \mathrm{~g}$ tissue of leaf in $2 \mathrm{ml}$ of $0.2 \mathrm{M}$ citrate phosphate buffer ( $\mathrm{pH} 6.5$ ) at $4^{\circ} \mathrm{C}$. The homogenate was centrifuged at $15,000 \mathrm{~g}$ at $4{ }^{\circ} \mathrm{C}$ for $30 \mathrm{~min}$ The supernatant served as enzyme source and SOD activity was determined as its ability to inhibit the photochemical reduction of NBT (Giannospolitis and Ries, $1977)^{[14]}$. The assay mixture $(3 \mathrm{ml})$ contained $50 \mathrm{mM}$ sodium phosphate buffer ( $\mathrm{pH} 7.8$ ), $13 \mathrm{mM}$ methionine, $75 \mu \mathrm{M}$ NBT, $2 \mu \mathrm{M}$ riboflavin. $0.1 \mathrm{mM}$ EDTA and $100 \mu \mathrm{l}$ of the enzyme extract and the riboflavin was added at the end. Tubes were shaken and placed under a $40-\mathrm{W}$ fluorescent lamp at $25^{\circ} \mathrm{C}$. The reaction was initiated and terminated by turning the light on and off respectively. The absorbance at $560 \mathrm{~nm}$ was measured against identical non-illuminated in parallel to the sample tubes for blank. Each extract was subtracted from the blank and mathematical difference was then divided by blank and multiplied by 100 to obtain the percentage inhibition of NBT photo-reduction. The SOD activity was expressed in SOD units $\mathrm{g}^{-1}$ tissue $(50 \%$ NBT inhibition $=1$ unit) (Belid ElMoshaty et al., 1993) ${ }^{[3]}$.

\section{Assay of catalase (CAT)}

CAT activity was assayed spectrophotometrically as described by Chaparro-Giraldo et al. (2000) ${ }^{[4]}$ using $3 \mathrm{ml}$ assay mixture containing $100 \mathrm{mM}$ potassium phosphate buffer ( $\mathrm{pH} 7.5$ ) and $2.5 \mathrm{mM} \mathrm{H}_{2} \mathrm{O}_{2}$ prepared immediately before use and $100 \mu \mathrm{l}$ enzyme extract. The activity was measured by monitoring the degradation of $\mathrm{H}_{2} \mathrm{O}_{2}$ using UV-Visible Spectrophotometer (Varian Cary 50) at $240 \mathrm{~nm}$ over 1 min, against a plant extract-free blank. The decrease in $\mathrm{H}_{2} \mathrm{O}_{2}$ was followed as the decline in optical density at 240 $\mathrm{nm}$, activity was calculated using the extinction coefficient $\left(\varepsilon_{240 \mathrm{~nm}}=40 \mathrm{mM}^{-1} \mathrm{~cm}^{-1}\right)$ for $\mathrm{H}_{2} \mathrm{O}_{2}$ and expressed in $\mu \mathrm{mol} \mathrm{min} \mathrm{min}^{-1}$ $\mathrm{mg}^{-1}$ of plant tissue.

\section{Assay on peroxidase (PO)}

Assay of PO activity was carried out as per the procedure described by Hammerschmidt et al. (1982) ${ }^{[16]}$. The reaction mixture consisted of $2.5 \mathrm{ml}$ of a mixture containing 0.25 per cent $(\mathrm{v} / \mathrm{v})$ guaiacol in $0.01 \mathrm{M}$ sodium phosphate buffer, $\mathrm{pH}$ 6.0 and $0.1 \mathrm{M}$ hydrogen peroxide. Enzyme extract $(0.1 \mathrm{ml})$ 
was added to initiate the reaction, which was followed colorimetrically at $470 \mathrm{~nm}$. Crude enzyme preparations were diluted to give changes in absorbance at $470 \mathrm{~nm}$ of 0.1 to 0.2 absorbance units/min. The boiled enzyme was used as blank. Activity was expressed as the increase in absorbance at 420 $\mathrm{nm} \mathrm{min}{ }^{-1} \mathrm{mg}^{-1}$ of plant tissue.

\section{Assay of polyphenoloxidase (PPO)}

One gram of sample was homogenized in $2 \mathrm{ml}$ of $0.1 \mathrm{M}$ sodium phosphate buffer $(\mathrm{pH} 6.5)$ at $4^{\circ} \mathrm{C}$. The homogenate was centrifuged at $20,000 \mathrm{~g}$ for $15 \mathrm{~min}$ at $4^{\circ} \mathrm{C}$. The supernatant served as enzyme source and polyphenoloxidase activity was determined as per the procedure given by Mayer et al. (1965) ${ }^{[22]}$. The reaction mixture consisted of $1.5 \mathrm{ml}$ of $0.1 \mathrm{M}$ sodium phosphate buffer $(\mathrm{pH} 6.5)$ and $200 \mu \mathrm{l}$ of the enzyme extract. To start the reaction, $200 \mu$ of $0.01 \mathrm{M}$ catechol was added and the activity was expressed as change in absorbance at $470 \mathrm{~nm} \mathrm{~min}^{-1} \mathrm{mg}^{-1}$ of plant tissue.

\section{Statistical analysis}

Data was subjected to analysis of variance and Duncan's multiple range tests was used to differentiate means as described by Duncan (1955). Values were considered at a significance level of $95 \%(p<0.05)$. Statistical analyses were performed using WASP-Web Agri Stat Package 2.0.

\section{Result and discussion}

A fast screening method would be helpful in selecting valuable genotypes with defined growth strategies that translate to drought tolerance and are suitable for experiment and/or breeding (Meher et al., 2018) ${ }^{[23]}$. The attainment of a drought tolerance screening method depends on identifying a critical level of stress induced by a particular concentration of an agent capable of inducing moisture stress (Yohannes et al., 2014; Harish Babu and Gobu, 2016) ${ }^{[33,17]}$. In this present investigation, the plants were short-term drought stressed by PEG-6000 with various concentrations for inducing variable degrees of osmotic stress. Analysis of variance revealed significant for different traits in small cardamom cv. Appangala-1 at various concentrations of PEG-6000.

\section{Growth characters}

The per cent of survival in small cardamom differed from 30 to 100 at various concentrations of PEG-6000 and it was 100 per cent in case of control (0\% PEG-6000) (Fig.1). Reduction in per cent survival $(50 \%$ and $70 \%)$ were recorded at 15 and $20 \%$ PEG-6000 concentration respectively compared to control as PEG 6000 is known to induce osmotic stress which affects per cent germination and survival in many crop plants at varying concentrations (Harish Babu and Gobu, 2016) ${ }^{[17]}$.

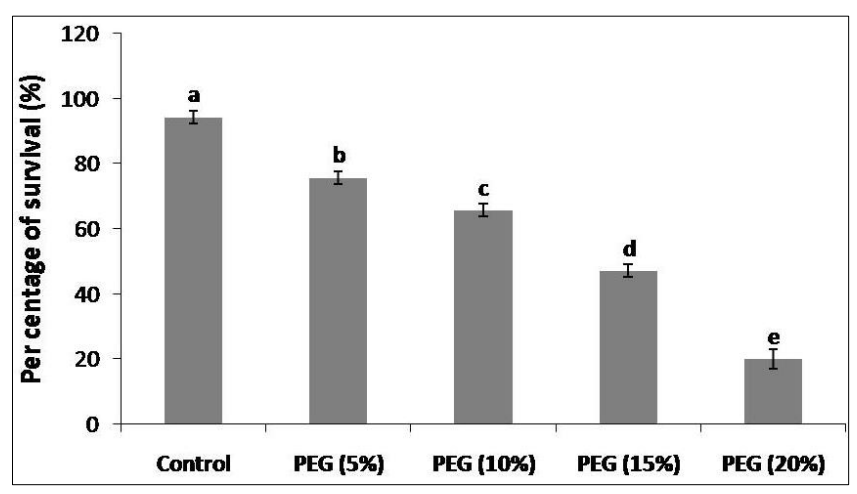

\section{Physio-chemical constituents}

\section{Photosynthetic pigments}

The reduction of photosynthesis driven by lower chlorophyll contents has been observed in numerous plants in response to drought stress (Chaves et al. 2002) ${ }^{[5]}$. In our present report it was observed that PEG-6000 treatment caused a decline in the contents of Chlorophyll 'a', 'b', and total Chlorophyll (Fig. 2). The reduction in chlorophyll content due to drought by producing reactive oxygen species (ROS) such as $\mathrm{O}_{2}^{-}$and $\mathrm{H}_{2} \mathrm{O}_{2}$, can led to lipid peroxidation and consequently, chlorophyll destruction also, with decreasing chlorophyll content (Farooq et al. 2009 and Meher et al., 2018) ${ }^{[10,23] .}$

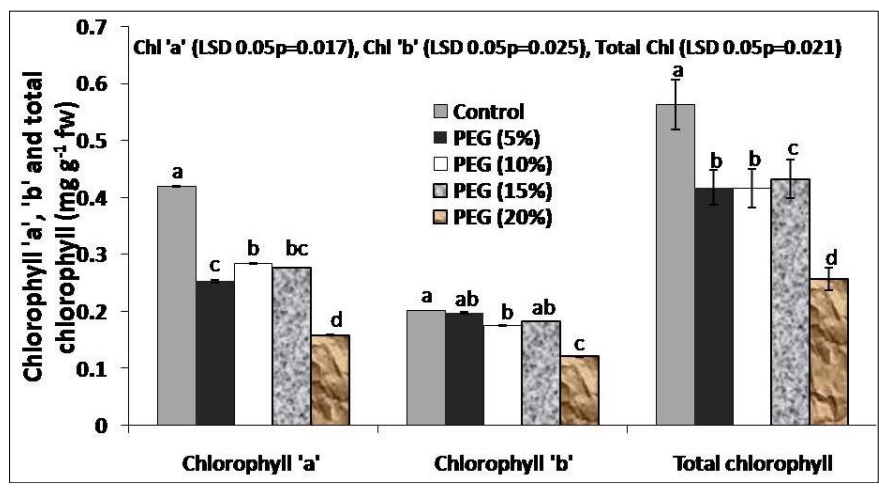

Total soluble protein and total phenol concentrations

Similar to chlorophyll content, the highest total soluble protein was observed in control treatment (Fig. 3). In vitro drought stress by PEG-6000 significantly reduces total soluble protein in leaves of treated plants and as the concentration decreases, small cardamom showed lower concentration of total soluble protein at PEG 20\% and similar findings have been reported by Mohd. Aminur Faiz Suis et al., (2015) ${ }^{[26]}$.

The total phenolic content was significantly higher under PEG-6000 induced drought stressed plant than the control. The treatment PEG 20\% (18.4 mg/g FW) showed the highest increase in phenolic contents when exposed to drought conditions compared to the control (5.69 mg/g FW) (Fig. 4). In small cardamom under drought induced drought stress related metabolic alterations and free radical production. In this condition small cardamom need more supply of phenolics for tolerance and prevent the oxidative damage of the cells. As a result, the metabolic processes are shifted towards biosynthesis of highly reduced phenolic in the stressed plant for better adaptation and similar findings have been reported by Natesan and Subramanian (2017) ${ }^{[28]}$.

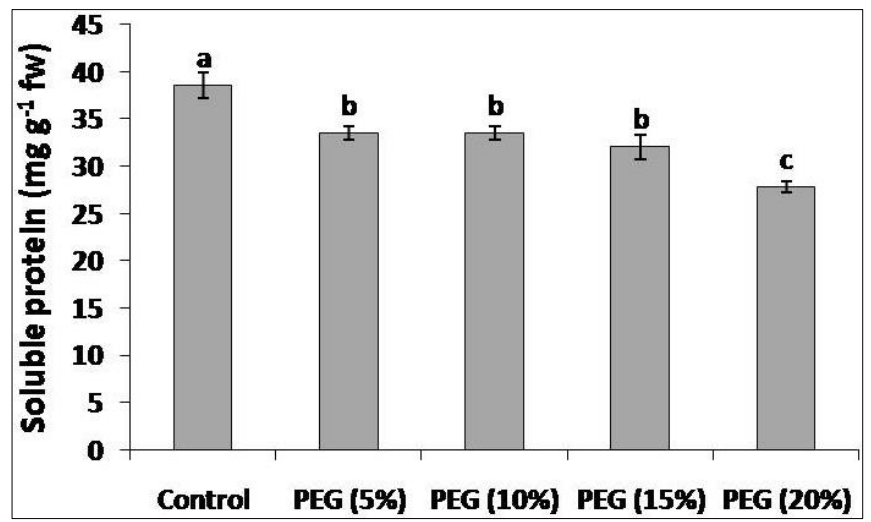




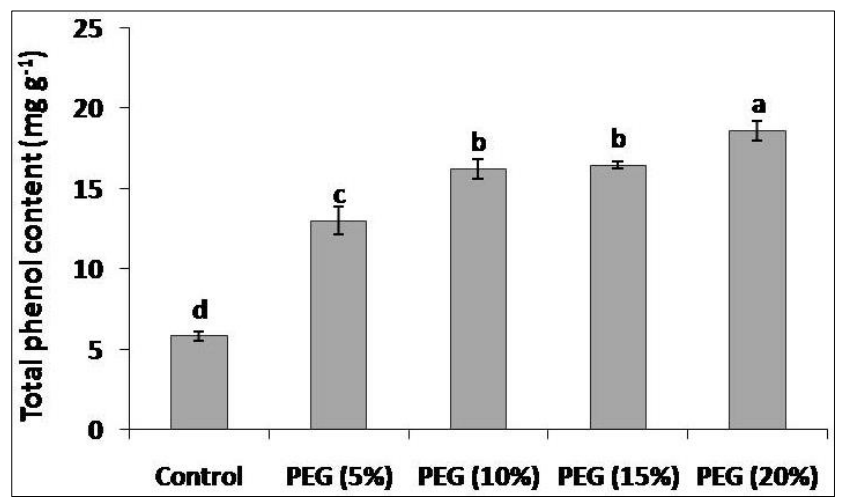

\section{Proline content}

The proline accumulation has the linearity to osmotic stress (Ghorbanli et al., 2012) ${ }^{[13]}$. In our study, proline content increased gradually, but the extent of this increase was significantly different $(p<0.05)$ in the treatments, and the maximum proline accumulation was observed in PEG $15 \%$ $\left(65.4 \mu \mathrm{g} \mathrm{g}^{-1} \mathrm{FW}\right)$, whereas the lowest was in control $(28.4 \mu \mathrm{g}$ $\mathrm{g}^{-1} \mathrm{FW}$ ) (Fig. 5). Elevated proline content under drought stress is proposed to cell water level and thus preventing plants from damages. The increased proline contents were observed in our study and similar findings have been reported by Javed and Ikram et al., $2008^{[18]}$.

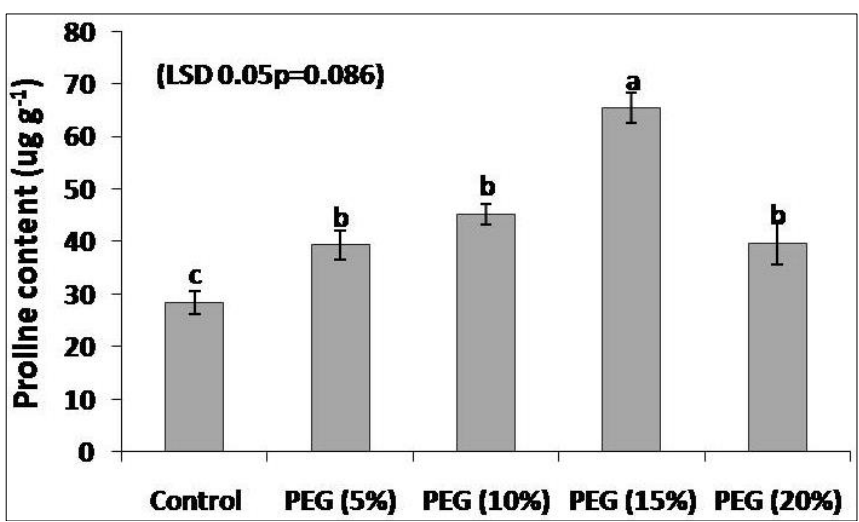

\section{Antioxidant enzyme activities}

The activity of enzymes (SOD, CAT, APX and PPO) involved in ROS scavenging varied significantly $(p<0.05)$ upon drought treatment (Fig. 6-9). Antioxidant activities of small cardamom leaves showed noticeable impact when PEG6000 was treated in hydroponic solution. Based on Fig. 6, leaves in control plants showed relatively low total SOD activities. The SOD activities of leaves treated with 10 and $15 \%$ PEG-6000 were then significantly induced more production of ROS. SOD is the first line of plant defense system against uncontrolled oxidation during unfavorable conditions. Cruz de Carvalho (2008) [7] reported that scavenging activity of SOD includes the conversion of highly reactive singlet oxygen molecules into more stable hydrogen peroxide. In the present investigation, SOD activity was significantly the highest in drought stressed plant as compared to control (Fig. 6).

Similar pattern of antioxidant activity was also exhibited by CAT activity (Fig. 7). As concentration of PEG-6000 increases, CAT activity of treated plant leaves increases. Nevertheless, control, 5\%, $10 \%$ and 15\% PEG treated plant leaves produced higher CAT activity compared to $20 \%$ PEG 6000 treated plant leaves. Perhaps this might be due to the low affinity of CAT towards hydrogen peroxide. Cruz de Carvalho (2008) ${ }^{[7]}$ stated that the enzyme CAT has low affinity for hydrogen peroxide and effective only in high concentration of hydrogen peroxide. In fact, high concentration of PEG 6000 in hydroponic medium induced excessive production of hydrogen peroxide in leaves which was favorable to the enzyme CAT and similar findings have been reported by Mohd. Aminur Faiz Suis et al. (2015) ${ }^{[26]}$.

Shigeoka et al. (2002) ${ }^{[31]}$ claimed that the APX exist as isoenzymes and has an important role in metabolism of hydrogen peroxide in higher plants. Lower APX activity of leaves at 10\%, 15\% and 20\% PEG 6000 (Fig. 8) could be due to the impact of drastic degradation of chlorophyll. Besides that, present study also implied that the activity of APX and PPO were observed highest in control leaves (Fig. 8). Unfortunately, activity of APX and PPO decreased as the concentration of PEG-6000 increases (Fig. 8\&9). These enzymes played a major role in maintaining the optimum level of reactive oxygen species which were involved in plant signaling and defense mechanism (Cruz de Carvalho 2008) ${ }^{[7]}$.
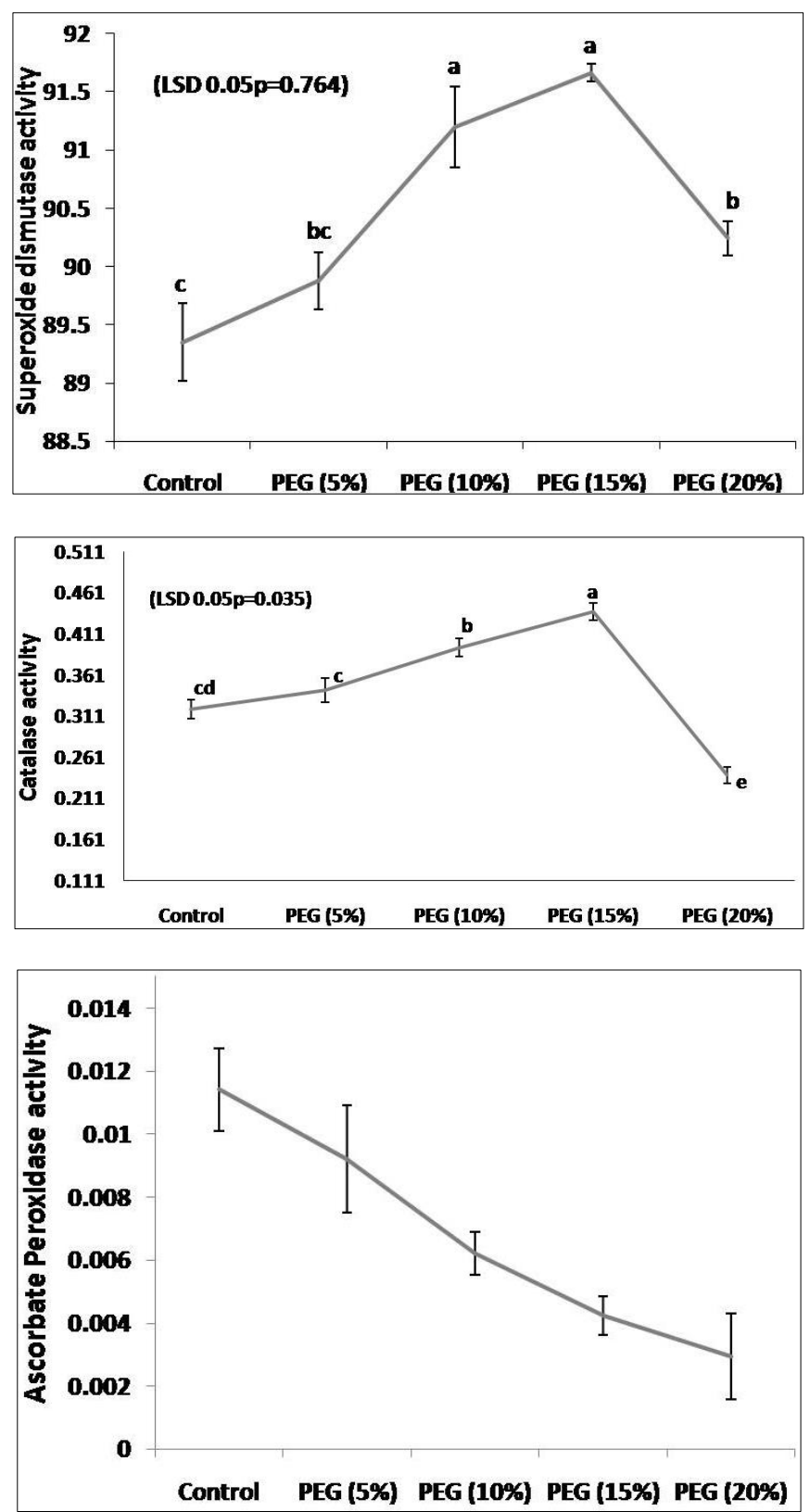


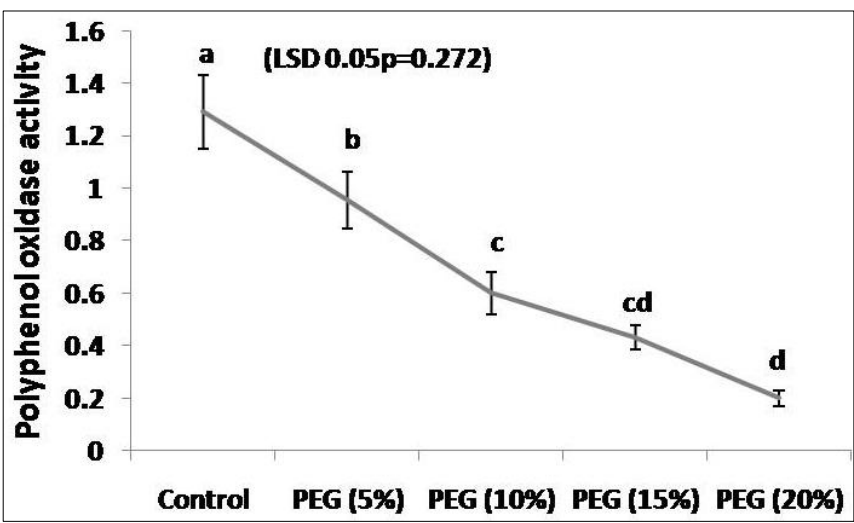

\section{Chlorophyll fluorescence}

The chlorophyll fluorescence parameter characterized by the maximal photochemical efficiency PSII $(\mathrm{Fv} / \mathrm{Fm})$ is widely used to determine the photosynthetic activity or efficiency of a plant (Dalton et al., 1998) ${ }^{[8]}$. PEG-6000 treatment decreased the $\mathrm{Fv} / \mathrm{Fm}$ values indicate a lower photosynthetic efficiency, with damages to the enzymatic apparatus of both photosystems I and II (Živčák et al. 2008) ${ }^{[35] . ~ I n ~ p r e s e n t ~}$ study, a significant decrease in the $\mathrm{Fv} / \mathrm{Fm}$ ratio was observed in all the treatments during the drought stress, suggesting a possible inhibition of PSII photochemistry by an insufficient energy transfer from the light harvesting chlorophyll complex to the reaction center (Fig. 10).

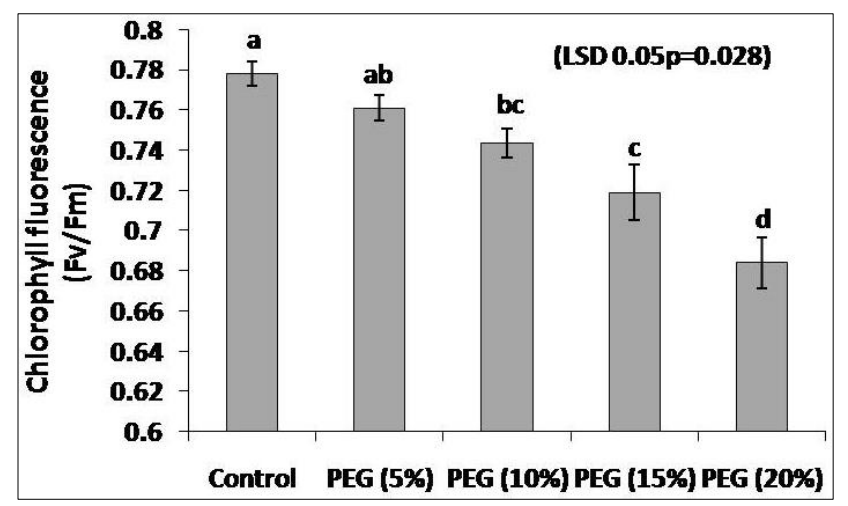

\section{Conclusion}

Based on the findings of the present investigation, the PEG6000 at $15 \%$ concentration (equivalent to -2.95 bars) can be used for screening a large number of germplasm collections of small cardamom in a short time under in vitro conditions.

\section{Acknowledgements}

The authors thank the Director, ICAR-Indian Institute of Spices Research, Kozhikode for providing facilities and Indian Council of Agricultural Research, New Delhi for financial support.

\section{References}

1. Alagupalamuthirsolai M, Ankegowda SJ, Krishnamurthy KS. Effect of Different Shade Levels on Growth, Physiology and Biochemical Characteristics of Small Cardamom (Elettaria cardamomum Maton). Current Journal of Applied Science and Technology. 2018; 28(3):1-9.

2. Bates LB, Waldren RP, Teare ID. Rapid determination of free proline for water stress studies. Plant and Soil. 1973; 39:205-207.
3. Belid El-Moshaty FIB, Pike SM, Novacky AJ, Seghal OP. Lipid peroxidation and superoxide production in cowpea (Vigna unguiculata) leaves infected with Tobacco ring spot virus or Southern bean mosaic virus. Physiol. Mol. Plant Pathol. 1993; 43:109-119.

4. Chaparro-Giraldo A, Barata RM, Chabregas SM, Azevedo, RA, Silva-Filho MC. Soybean leghemoglobin targeted to potato chloroplasts influences growth and development of transgenic plants. Plant Cell Rep. 2000; 19:961-965.

5. Chaves MM, Pereira JS, Maroco J, Rodrigues ML, Ricardo CPP, Osório ML et al. How plants cope with water stress in the field? Photosynthesis and growth. Ann Bot. 2002; 89(7):907-916.

6. Claussen W. Proline as a measure of stress in tomato plants. Plant Sci. 2005; 168:241-248.

7. Cruz de Carvalho MH. Drought stress and reactive oxygen species: Production, scavenging and signaling. Plant Signal Behav. 2008; 3:156-165.

8. Dalton DA, Joyner SL, Becana M Iturbe-Ormaetxe I, Chatfield JM. Antioxidant defenses in the peripheral cell layers of legume root nodules. Plant Physiol. 1998; 116:37-43.

9. Epstein E. Mineral Nutrition of Plants: Principles and Perspectives. Wiley, New York, 1972.

10. Farooq M, Wahid A, Kobayashi N, Fujita D, Basra S. Plant drought stress: effects, mechanisms and management. Sustainab Agric Springer. 2009; 29(1):153188.

11. Fernandez-Ocana A, Chaki M, Luque F, GomezRodriguez MV, Carreras A, Valderrama $\mathrm{R}$ et al. Functional analysis of superoxide dismutases (SODs) in sunflower under biotic and abiotic stress conditions. Identification of two new genes of mitochondrial MnSOD. J. Plant Physiol. 2011; 168:1303-1308.

12. Foyer $\mathrm{CH}$, Noctor G. Oxidant and Antioxidant Signalling in Plants: A Re-Evaluation of the concept of oxidative stress in a physiological context. plant cell \& environmental. 2005; 28:1056-1071.

13. Ghorbanli M, Gafarabad M, Amirkian T, Mamaghani BA. Investigation of proline, total protein, chlorophyll, ascorbate and dehydro-ascorbate changes under drought stress in Akria and Mobil tomato cultivars. Ir. J. Plant Physiol. 2012; 3:651-658.

14. Giannospolitis CN, Ries SK. Superoxide dismutase. Plant Physiology. 1977; 59:309-314.

15. Hamayun M, Khan SA, Shinwari ZK, Khan AL, Ahmad N, Lee IJ. Effect of polyethylene glycol induced drought stress on physio-hormonal attributes of soybean. Pak. J. Bot. 2010; 42:977-986.

16. Hammerschmidt R, Nuckles EM, Kuc J. Association of enhanced peroxidase activity with induced systemic resistance of cucumber to Colletotrichum lagenarium. Physiol. Plant Pathol. 1982; 20:73-82.

17. Harish Babu BN, Gobu R. Optimization of osmotic stress induced by different concentrations of Polyethylene glycol-6000 for drought tolerance screening in egg plant (Solanum melongena L.,). International Journal of Scientific Research. 2016; 5(2):205-206.

18. Javed F, Ikram S. Effect of sucrose induced osmotic stress on callus growth and biochemical aspects of two wheat genotypes. Pak. J. Bot. 2008; 40:1487-1495.

19. Kaur C, Kapoor HC. Anti-oxidant activity and total phenolic content of some Asian vegetables. Int. J. Food Sci. Technol. 2002; 37:53-161. 
20. Kishor KPB, Sreenivasulu N. Is proline accumulation per se correlated with stress tolerance or is proline homeostasis a more critical issue. Plant Cell Environ. 2014; 37:300-311.

21. Lowry $\mathrm{OH}$, Rosebrough NJ, Farr AL. Protein measurement with the Folin phenol reagent. J Biol Chem. 1951; 193:265-276.

22. Mayer AM, Harel E, Shaul RB. Assay of catechol oxidase a critical comparison of methods. Phytochemistry. 1965; 5:783-789.

23. Meher P, Shivakrishna K, Ashok Reddy D, Manohar Rao. Effect of PEG-6000 imposed drought stress on RNA content, relative water content (RWC), and chlorophyll content in peanut leaves and roots, Saudi Journal of Biological Sciences. 2018; 25:285-289.

24. Meneses CHSG, Bruno RLA, Fernandes RD, Pereira WE, Lima WHGM, Lima MMA et al. Germination of cotton cultivar seeds under water stress induced by polyethyleneglycol-6000. Sci. Agric. (Piracicaba, Braz.), 2011, 68.

25. Mohammadkhani N, Heidari R. Water stress induced by polyethylene glycol 6000 and sodium chloride in two maize cultivars. Pak. J. Biol. Sci. 2008; 11:92-97.

26. Mohd. Aminur Faiz Suis, Khor Soo Ping, chee keong Chin, Sreeramanan Subramaniam. Biochemical and physiological responses to polyethylene glycol (PEG) treatment in protocorm-like bodies (PLBs) of Aranda Broga Blue Bell. Emirates Journal of Food and Agriculture. 2015; 27(10):776-783.

27. Murugan M, Mukund V, Ramesh R, Hiremath MB. Centennial rainfall variation in semi arid and tropical humid environments in the cardamom hill slopes, southern Western Ghats, India. Casp J Environ Sci. 2008; 6(2):31-39.

28. Natesan G, Subramanian K. Drought stress signal promote the synthesis of more reduced phenolic compounds (Chloroform insoluble fraction) in Tridax procumbens. Free Radicals and Antioxidants. 2017; 7(1):128-136.

29. Prasada Rao GSLHV. Weather extremes and plantation crops in the humid tropics. Mausam. 2016; 67(1):251258.

30. Sakthivelu G, Devi MKA, Giridhar P, Rajasekaran T, Ravishankar GA, Nedev $\mathrm{T}$ et al. Drought-induced alterations in growth, osmotic potential and in vitro regeneration of soybean cultivars. Genet. Appl. Plant Physiol. 2008; 34:103-112.

31. Shigeoka S, Ishikawa T, Tamoi M, Miyagawa Y, Takeda $\mathrm{T}$, Yabuta $\mathrm{Y}$ et al. Regulation and function of ascorbate peroxidase isoenzymes. J. Exp. Bot. 2002; 53:1305-1319.

32. Xu XM, Lin H, Maple J, Björkblom B, Alves G, Larsen JP et al. The Arabidopsis DJ-1a protein confers stress protection through cytosolic SOD activation. J. Cell Sci. 2010; 123:1644-1651.

33. Yohannes $\mathrm{T}$, Mebeaselassie $\mathrm{A}$, Abuhay $\mathrm{T}$. In vitro selection of sorghum (Sorghum bicolor (L) Moench) for polyethylene glycol (PEG) induced drought stress. Plant Sci. Today. 2014; 1(2):62-68.

34. Zhang J, Liu JF, Zhao TT, Xu XY. Effects of drought stress on chlorophyll fluorescence in tomato, Molecular Plant Breeding. 2017; 8(7):65-69.

35. Živčák $M$, Breštič $M$, Olšovska $K$, Slamka $P$. Performance index as a sensitive indicator of water stress in Triticum aestivum L. Plant Soil Environ. 2008; 54:133139. 